\title{
Analisis Politik Luar Negeri Indonesia-China di Era Presiden Joko Widodo: Benturan Kepentingan Ekonomi dan Kedaulatan?
}

\author{
Muhammad Tri Andika \\ Allya Nur Aisyah \\ Universitas Bakrie
}

\begin{abstract}
Abstrak
Di era Presiden Joko Widodo, kedekatan hubungan Indonesia terhadap China mengalami peningkatan. Hal ini terutama ditandai dengan peningkatan kerjasama ekonomi kedua negara, baik pada sektor investasi maupun perdagangan. Meski demikian, hubungan kedua negara juga memiliki ketegangan pada bidang kedaulatan teritori, terutama dalam penyikapannya terhadap isu perairan Natuna di sekitaran Laut China Selatan. Dengan profil yang tampak bersebarangan tersebut, di bidang ekonomi terjalin kedekatan namun pada isu kedaulatan terjadi ketegangan, apakah dua dinamika yang berbeda ini saling mempengaruhi? Tulisan ini mengangkat suatu argumen bahwa dua dinamika berbeda yang melingkari hubungan Indonesia-China, tidak memiliki pengaruh yang signifikan satu sama lain. Hal ini disebabkan diplomasi Indonesia dengan China dalam bidang ekonomi dan kedaulatan memiliki karakter dan struktur kepentingan yang berbeda. Pada bidang ekonomi, hubungan Indonesia dan China dijalin atas prinsip kerjasama yang pragmatis dalam upaya peningkatan hubungan perdagangan dan investasi. Sementara pada bidang kedaulatan, hubungan kedua negara berpijak pada prinsip kepentingan strategis. Artikel ini juga berargumentasi bahwa aliran investasi China ke Indonesia dalam sejumlah pembiayaan infrastruktur, tidak mempengaruhi ketegasan Indonesia dalam mempertahankan kedaulatan Natuna.
\end{abstract}

Kata-kata kunci: Indonesia, China, Natuna, Investasi

\begin{abstract}
Under Joko Widodo presidency, relations between Indonesia and China has increased dramatically. It is mainly marked by set of effort to intensify economic cooperation between the two countries, both in the investment and trade sectors. However, at the same time the two countries also involve in the territorial disputes, particularly in the Natuna's waters area. Against that background, do these two different dynamics affect each other? This paper argues that two distinct dynamics circling the Indonesia-China relationship have no significant influence each other. This is because Indonesia's diplomacy with China in economic and sovereignty has different character and structure of interests. In the economic field, relations between Indonesia and China have been pursued on the principle of pragmatic cooperation in the effort to increase trade and investment relations. While in the Natuna's issue the relationship between the two countries is based on the principle of strategic importance. This article also argues that China's investment flows to Indonesia in some infrastructure financing, does not affect Indonesia's firmness in maintaining Natuna's sovereignty.
\end{abstract}

Keywords: Indonesia, China, Natuna, Investment 


\section{Pendahuluan}

Hubungan Indonesia-China mengalami penguatan di era Presiden Joko Widodo (Jokowi). Ekspansi pembangunan infrastruktur yang membutuhkan investasi besar, mendorong Indonesia untuk melakukan kerjasama ekonomi intensif dengan China. Namun pada saat bersamaan, hubungan Indonesia-China juga diwarnai ketegangan di perairan Natuna. Beberapa kali kapal nelayan China masuk ke dalam wilayah perairan Indonesia tanpa izin. Peristiwa ini tidak lepas dari klaim China di Laut China Selatan yang berbatasan dengan perairan Natuna. Dengan profil yang tampak berseberangan tersebut, di bidang ekonomi terjalin kedekatan namun pada isu kedaulatan terjadi ketegangan, apakah dua dinamika yang berbeda ini saling mempengaruhi?

Melalui program mega-infrastruktur China-OBOR (One Belt One Road), China juga berupaya melakukan pendekatan terutama terhadap negara-negara yang memiliki ketegangan dengannya di Laut China Selatan. OBOR yang diwujudkan dengan kerjasama investasi, menjadi instrumen China untuk mempengaruhi sikap negara-negara yang memiliki hubungan dengan Laut China Selatan. Sebagian negara berubah sikapnya. Namun tidak demikian dengan Indonesia.

Tulisan ini mengangkat argumen bahwa dua dinamika berbeda yang melingkari hubungan Indonesia-China, tidak memiliki pengaruh yang signifikan satu sama lain. Hal ini disebabkan diplomasi Indonesia dengan China dalam bidang ekonomi dan kedaulatan di perairan Natuna memiliki karakter dan struktur kepentingan yang berbeda. Pada bidang ekonomi, hubungan Indonesia dan China dijalin atas prinsip kerjasama yang pragmatis dalam upaya peningkatan hubungan perdagangan dan investasi. Sementara pada bidang kedaulatan, hubungan kedua negara berpijak pada prinsip kepentingan strategis. Artikel ini juga berargumentasi bahwa aliran investasi China ke Indonesia dalam sejumlah pembiayaan infrastruktur tidak mempengaruhi ketegasan Indonesia dalam mempertahankan kedaulatan Natuna.

Untuk sampai pada argumentasi tersebut, pada bagian selanjutnya dibahas faktor-faktor yang menjelaskan peningkatan hubungan Indonesia di era Presiden Jokowi dengan China. Setelah itu, tulisan ini mendiskusikan struktur kepentingan Indonesia dengan China dan kepentingan Indonesia di Laut China Selatan. Di bagian akhir tulisan ini, dipaparkan tentang dua kepentingan Indonesia dengan China yang berjalan pada koridor terpisah dan tidak saling mempengaruhi satu sama lain.

\section{China dan politik luar negeri Presiden Joko Widodo.}

Pada masa pemerintahan Presiden Jokowi, hubungan Indonesia dan China mengalami peningkatan yang cukup pesat. Bahkan, peningkatan tersebut menjadi sinyalemen kuat pergeseran politik luar negeri Indonesia terhadap China. Perhatian Presiden Joko Widodo terhadap China sudah ditunjukkan sejak awal masa jabatannya. Secara simbolis, China merupakan negara yang pertama kali 
dikunjungi Jokowi pada 8 November 2014. Kunjungan Jokowi tersebut bertepatan dengan Konferensi Tingkat Tinggi (KTT) APEC di Bejing China.

Sebagai negara pertama yang dikunjungi, tentu tidak bisa dilepaskan dari pemaknaan khusus bahwa China memiliki posisi strategis dalam politik luar negeri Jokowi. Dalam kunjungan itu, kedua negara mencapai kesepakatan-kesepakatan strategis. Misalnya, Jokowi menyatakan komitmennya untuk bergabung dengan China dalam pembentukan Asian Infrastructure Investment Bank (AIIB) yang dipimpin oleh China (Asia Sentinel, 2017). AIIB adalah lembaga keuangan internasional yang dipimpin oleh China yang dibentuk khusus untuk pembiayaan proyek infrastruktur. Lebih spesifik, AIIB dibentuk sebagai bank yang khusus mendukung inisiatif Silk Road China, yang fokus pada penyempurnaan hubungan di Asia, Timur Tengah, Afrika dan Eropa (AIIB, 2017).

Peningkatan hubungan Indonesia-China juga dapat dilihat dalam momen perayaan 65 tahun hubungan bilateral kedua negara. Pada perayaan 65 tahun hubungan Bilateral Indonesia-China, Jokowi melakukan kunjungan kembali ke China pada tanggal 25-28 Maret 2015. Lebih dari kunjungannya yang pertama, Jokowi dan Presiden China Xi Jinping membahas beberapa hal untuk meningkatkan hubungan kerjasama Indonesia dan China. Dua kepala negara memfokuskan pembicaraannya pada bidang ekonomi khususnya sektor perdagangan, keuangan, infrastruktur, perindustrian, pariwisata, hingga hubungan antara masyarakat (Duta, 2015). Sebagai hasil dari kunjungan kedua ini, Indonesia dan China berhasil menyepakati delapan MoU. Delapan MoU tersebut antara lain sebagai berikut (Kompas, 2015):

Tabel 1. MoU Indonesia-China pada Pertemuan Presiden Joko Widodo-Xin Jin Ping pada 65 tahun perayaan hubungan bilateral Indonesia-China

\begin{tabular}{|c|c|}
\hline No. & MoU \\
\hline 1 & $\begin{array}{l}\text { Nota kesepahaman kerja sama ekonomi antara Kemenko } \\
\text { Perekonomian RI dan Komisi Reformasi dan Pembangunan } \\
\text { Nasional China. }\end{array}$ \\
\hline 2 & $\begin{array}{l}\text { Nota kesepahaman kerja sama Proyek Pembangunan Kereta Api } \\
\text { Cepat Jakarta-Bandung antara Kementerian BUMN dan Komisi } \\
\text { Reformasi dan Pembangunan Nasional China. }\end{array}$ \\
\hline 3 & $\begin{array}{l}\text { Nota Kesepahaman kerja sama maritim dan SAR antara Basarnas } \\
\text { dan Kementerian Transportasi China. }\end{array}$ \\
\hline 4 & $\begin{array}{l}\text { Kerja sama antara Protokol Persetujuan antara Pemerintah China } \\
\text { dan RI dalam pencegahan pengenaan pajak ganda kedua negara. }\end{array}$ \\
\hline 5 & $\begin{array}{l}\text { Kerangka Kerja Sama Antariksa } 2015-2020 \text { antara Lapan dan } \\
\text { Lembaga Antariksa China. }\end{array}$ \\
\hline 6 & $\begin{array}{l}\text { Nota kesepahaman kerja sama saling dukung antara Kementerian } \\
\text { BUMN dan Bank Pembangunan China Pembangunan. }\end{array}$ \\
\hline 7 & $\begin{array}{l}\text { Nota kesepahaman antara pemerintah China dan RI dalam } \\
\text { pencegahan pengenaan pajak ganda kedua negara. }\end{array}$ \\
\hline 8 & $\begin{array}{l}\text { Nota kesepahaman kerja sama bidang industri dan infrastruktur } \\
\text { antara Kementerian BUMN dan Komisi Reformasi dan } \\
\text { Pembangunan Nasional China. }\end{array}$ \\
\hline
\end{tabular}


Sejak dilantik menjadi presiden pada 20 Oktober 2014, hingga saat ini Indonesia sudah memiliki $36 \mathrm{MoU}$ dengan China. 36 kesepakatan IndonesiaChina tersebut mencakup antara lain dalam bidang perekonomian, budaya, pendidikan, dan pariwisata. Hubungan kerjasama tersebut, sebagaimana tercatat oleh Kementerian Luar Negeri Indonesia, terdapat $36 \mathrm{MoU}$ baru Indonesia-China di era Jokowi.

Disepakatinya $36 \mathrm{MoU}$ Indonesia-China dalam waktu yang cukup singkat, menandakan keseriusan Indonesia dan China untuk menjalin hubungan yang lebih dekat. Dari gambaran tersebut, pertanyaan penting yang hendak dijawab kemudian adalah, kondisi apa yang membuat Indonesia membangun hubungan yang serius dengan China? Untuk menjelaskan alasan yang melatarbelakangi Indonesia mendekati China, argumentasi dalam artikel ini dibagi menjadi dua. Pertama adalah faktor eksternal dan kedua adalah faktor internal.

Dari faktor eksternal yang pertama, mendekatnya Indonesia ke China tidak terlepas dari kebangkitan China sebagai kekuatan ekonomi global di abad-21, atau yang biasa dikenal dengan istilah fenomena the Rise of China. Kebangkitan China adalah gambaran menguatnya perekonomian China yang didorong oleh kebijakan ekonomi pintu terbuka yang dimulai di era Deng Xiao Ping (1978-1987). Penerapan open door policy ini membawa China memasuki mordernitas ekonomi pasar. Kebijakan ini membawa China mengalami transformasi besar-besaran dalam struktur perekonomian nasionalnya. Sebelum diterapkan kebijakan ekonomi terbuka, tepatnya pada tahun 1970 perdagangan ekspor China hanya mencapai 0.7 persen dari total dunia atau 12 persen dari PDB. Situasi berubah pasca 1978 dimana China menjadi salah satu negara dengan perekonomian yang paling terbuka di dunia. Tarif impor China rata-rata turun dari 23.7 persen pada 2001 menjadi 5.7 persen pada 2011. Begitupun dengan stabilitas pertumbuhan ekonomi China yang mampu tumbuh 8 persen per tahun dengan jumlah penduduk 1,28 miliar jiwa. The Rise of China juga ditandai menguatnya ekspor yang berpengaruh terhadap surplus ekonomi China. Cadangan devisa China dari yang awalnya hanya mencapai US\$ 291 miliar pada 2002 menjadi US\$ 987,9 miliar pada 2006. Data IMF pada 2014 juga mencatat bahwa China berhasil melampaui AS dalam kontribusinya terhadap PDB dunia yang mencapai 17 persen, sementara AS hanya 16 persen (Kamrany, Jiang, 2016).

Upaya China dalam mengukuhkan dominasi ekonominya sejak tahun 2013 diperkuat dengan agenda ambisiusnya yang disebut dengan OBOR (One Belt One Road). Inilah faktor eksternal kedua yang mendorong kedekatan Indonesia dengan China. Dengan agenda OBOR, China memiliki rencana untuk merevitalisasi jalur sutera, jalur perdagangan yang menghubungkan Asia dengan Eropa, dalam projek pembangunan Silk Economic Road untuk jalur darat, dan 21 Maritime Silk Road untuk jalur laut. Rencana pembangunan proyek besar tersebut akan dibayai oleh AIIB, bank infrastruktur yang dipimpin oleh China. Dalam road map Silk Road Economic Belt dan 21st Century Maritime Slik Road, Indonesia termasuk 
negara yang berada pada jalur sutera maritim yang hendak China kembangkan. Dari kerangka ini, kepentingan China di Indonesia sangat jelas, yakni menjadikan Indonesia sebagai bagian yang terintegrasi dengan agenda pembangunan jalur sutera maritim China.

Faktor eksternal ketiga yang mempengaruhi mendekatnya Indonesia terhadap China adalah kegagalan AS dalam strategi rebalance to Asia. Kebangkitan ekonomi China mengancam posisi AS sebagai kekuatan ekonomi global. Sebagai respon terhadap posisi China yang terus meningkat, AS kemudian mengusung konsep Rebalance To Asia. Konsep Rebalance To Asia yang digagas AS adalah untuk meningkatkan keamanan regional dan kemakmuran ekonomi di kawasan Indo-Asia-Pasifik (Poole, 2017). Wujud nyata dari konsepsi rebalance to Asia, AS kemudian membentuk aliansi Trans- Pacific Partner (TPP) sebagai wadah kerja sama ekonomi bagi negara-negara terutama di kawasan Asia Pasifik. TPP merupakan pasar bebas yang diciptakan oleh AS, yang bertujuan untuk memperdalam hubungan ekonomi antara negara-negara dan mendorong perdagangan untuk mendorong pertumbuhan.

Namun sayangngya, konsep TPP yang direncanakan oleh AS tidak berjalan dengan lancar. Hal tersebut disebabkan presiden AS yang baru yaitu Donald Trump tidak mendukung program TPP (BBC, 2016). Program TPP merupakan program yang dibentuk pasa masa pemerintahan Presiden Barack Obama, bergantinya masa jabatan Presiden maka program TPP tidak berjalan sesuai dengan rencana sebelumnya. Dengan kebuntuan yang dialami TPP, Indonesia harus mencari poros yang lebih stabil dan dekat. Dalam hal ini, China menjadi pilihan rasional Indonesia untuk membangun aliansi strategis terutama di bidang ekonomi.

Selain tiga faktor eksternal tersebut, terdapat faktor internal yang mempengaruhi hubungan Indonesia-China. Faktor internal terutama sangat dipengaruhi dengan kebutuhan Indonesia untuk pembangunan infrastruktur. Indonesia di bawah pemerintahan Jokowi memiliki rencana pembangunan infrastruktur yang sangat ambisius. Anggaran yang dibutuhkan Indonesia untuk pembangunan infrastruktur tahun 2015-2019 sebesar Rp. 4.700 triliun (Bappenas, 2015). Pemerintah Indonesia tidak dapat membiayai seluruh pembangunan infrastruktur, oleh sebab itu Indonesia membutuhkan investasi asing untuk pembiayaan pembangunan infrastruktur.

China dengan program Belt and Road Initiative yang akan memberikan dana bantuan investasi pembangunan infrastruktur, tentunya sangat menarik perhatian Indonesia. Program kereta api cepat (Hight Speed Train/HST) merupakan salah satu program proyek pendanaan yang mencerminkan agenda OBOR China. Untuk membangun jalur OBOR atau Belt and Road Initiative, China membutuhkan dukungan negara-negara Asian Tiger (Forbes, 2017). Dalam konteks tersebut, China melihat Indonesia sebagai salah satu Asian Tiger yang dapat membantu terbentuknya strategi One Belt and One Road Initiative (Cai, 2017). 
Faktor internal selanjutnya adalah faktor idiosinkratik. Idiosinkratik merupakan salah faktor dari kebijakan luar negeri suatu negara yang dibentuk berdasarkan psikologi pemimpin untuk membentuk kebijakan luar negeri tersebut. Sebagaimana dijelaskan dalam kerangka teoritik James Rosenau, terdapat lima variabel yang mempengaruhi dibentuknya kebijakan luar negeri yaitu, sistem pemerintahan, masyarakat, aturan dan idiosinkratik (Tayfur, 1994). Di era Jokowi, Indonesia tampak memiliki kedekatan khusus dengan China. Artikel ini berpendapat bahwa kedekatan Indonesia dengan China di era Presiden Jokowi dipengaruhi oleh kedekatan antara PDIP dimana status Jokowi yang merupakan kader partai dan Partai Komunis China (Communist Party of China /CPC). Hal ini tercermin dari beberapa kegiatan yang terjalin oleh kedua belah pihak. Sebagai contoh kedekatan antara PDIP dan PKC terlihat dari cukup intensifnya interaksi kedua belah pihak. Kedekatan ini semakin ditegaskan pada 13 Mei 2016, saat Jokowi menerima delegasi Partai Komunis China di Istana Medeka. Pada pertemuan tersebut, dicapai kesepakatan untuk meningkatkan hubungan persahabatan kedua negara pada tingkat pemerintah dan partai (Kompas, 2017a). Kedekatan antara PDIP dan Partai Komunis China, tentu memiliki pengaruh terhadap hubungan Indonesia dan China.

Selain itu, kedekatan Indonesia dengan China juga sangat dipengaruhi oleh orientasi politik luar negeri Jokowi. Jargon kebijakan luar negeri Jokowi adalah "diplomasi membumi" atau "diplomasi pro-rakyat". Diplomasi prorakyat merupakan diplomasi dimana kepentingan domestik menjadi acuan bagi pembentukan kebijakan luar negeri Indonesia (Andika, 2016). Model diplomasi Indonesia saat ini menjadi salah satu faktor internal meningkatnya hubungan Indonesia dan China. China dengan segenap rencana kebijakannya yang ekspansif dipandang sebagai negara yang dapat mendorong tercapainya kebutuhan domestik Indonesia saat ini.

Sebagai kesimpulan, lingkungan eksternal dan internal menjadi faktor yang memperkuat hubungan China dan Indonesia saat ini. Persinggungan kedua faktor tersebut mendorong kecondongan politik luar negeri Jokowi terhadap China sebagai mitra ekonomi dibanding relatif terhadap AS. Meningkatnya hubungan kedua negara ini membawa dinamika baru dalam hubungan Indonesia-China. 
Tabel 2. Riwayat hubungan bilateral Indonesia-China 2014-2017

\begin{tabular}{|l|l|}
\hline 1. & $\begin{array}{l}\text { 8 November } 2014 \text { : Presiden Jokowi melakukan kunjungan luar negeri } \\
\text { pertama sebagai Presiden ke negara China. }\end{array}$ \\
\hline 2. & $\begin{array}{l}\text { 25-28 Maret } 2015 \text { : Kunjungan Bilateral Presiden Jokowi ke China dalam } \\
\text { rangka perayaan } 65 \text { tahun hubungan Bilateral Indonesia-China. }\end{array}$ \\
\hline 3. & $\begin{array}{l}\text { 22 April } 2015: \text { Presiden Xi Jinping hadir dalam } 60 \text { tahun Konfersi Asia } \\
\text { Afrika (KAA) di Bandung, Indonesia. }\end{array}$ \\
\hline 4. & $\begin{array}{l}\text { 27 Mei 2015 : Perdana Menteri China Liu Yandong melakukan } \\
\text { kunjungan ke Indonesia untuk bertemu dengan Presiden Jokowi. }\end{array}$ \\
\hline 5. & $\begin{array}{l}\text { 10 Agustus } 2015: \text { Menteri Pembangunan Nasional dan Reformasi } \\
\text { Republik Rakyat Tiongkok, Xu Shaoshi melakukan kunjungan ke } \\
\text { Indonesia dan bertemu dengan Presiden Jokowi. }\end{array}$ \\
\hline 6. & $\begin{array}{l}\text { 9 Mei 2016: Menteri Koordinator bidang Politik, Hukum, dan } \\
\text { Keamanan, Luhut Binsar Pandjaitan, bertemu dengan Anggota Dewan } \\
\text { Negara China Yang Jiechi. }\end{array}$ \\
\hline 7. & $\begin{array}{l}\text { 13 Mei 2016 : Delegasi Partai Komunis Tiongkok bertemu dengan } \\
\text { Presiden Jokowi di Indonesia. }\end{array}$ \\
\hline 8. & $\begin{array}{l}\text { 2 September 2016 : Presiden Jokowi melakukan kunjungan Bilateral ke } \\
\text { China. }\end{array}$ \\
\hline 9. & $\begin{array}{l}\text { 4-5 September 2016 : Presiden Jokowi melakukan kunjungan ke China } \\
\text { dalam rangka Konferensi Tingkat Tinggi (KTT) G20. }\end{array}$ \\
\hline 10. & $\begin{array}{l}\text { 14-15 Mei 2017: Presiden Jokowi hadir dalam pembukaan KTT Belt and } \\
\text { Boad Forum di China National dan akan melakukan pertemuan } \\
\end{array}$ \\
\hline
\end{tabular}

\section{Struktur kepentingan Indonesia-China}

Artikel ini mengusung argumentasi bahwa hubungan Indonesia-China pada era Jokowi dibentuk oleh dua kepentingan utama, yaitu kepentingan ekonomi dan kepentingan kedaulatan terutama dalam konteks Laut China Selatan dan Natuna. Namun demikian, artikel ini juga berpendapat bahwa kedua kepentingan tersebut meskipun hadir secara bersamaan, tidak saling mempengaruhi satu sama lain. Dengan kata lain, kepentingan Indonesia-China di bidang ekonomi tidak mempengaruhi kepentingan Indonesia dalam isu Laut China Selatan khususnya di Natuna. Hal ini disebabkan antara dua kepentingan tersebut memiliki batas yang ditunjukan oleh sikap tegas Indonesia terhadap sikap agresif China di Natuna.

Dalam aspek ekonomi, kepentingan kedua negara terdiri dari kerjasama investasi dan perdagangan. Indonesia saat ini membutuhkan investasi besar dari China sebagai negara yang memiliki sumber investasi untuk membiayai rencana pembangunan infrastruktur. Begitupun dalam bidang perdagangan, kedua negara telah menjalin hubungan yang sangat erat untuk pertukaran komoditas strategisnya. Namun dalam bidang kedaulatan, Indonesia memiliki kepentingan untuk menjaga status perairan Natuna dari klaim China. Klaim China terhadap Laut China Selatan memiliki implikasi pada sikap China di perairan Natuna. Kedua negara bersitegangan pada dimensi ini. Namun demikian, artikel ini berpendapat bahwa konflik kedua negara di bidang kedaulatan tidak menganggu jalannya kerjasama di bidang ekonomi dan juga sebaliknya. 


\section{Hubungan Investasi Indonesia-China}

Investasi menjadi pusat perhatian Indonesia terhadap China, terutama untuk membiayai pembangunan infrastruktur. Di masa pemerintahan Jokowi investasi China di Indonesia meningkat dari tahun-tahun sebelumnya. Pada tahun 2015 investasi China meningkat sebesar 26 persen menjadi US\$ 628 juta. Pada triwulan I 2016 investasi meningkat sebesar kurang lebih US\$ 1miliar (BKPM, 2017). Total investasi China di Indonesia sepanjang tahun 2016 adalah US\$ 2,7 miliar dengan jumlah proyek 1.734 buah. Saat ini China menempati posisi ketiga sebagai sumber investor asing di Indonesia. Selain itu, pasca disepakatinya kerjasama Indonesia dan China, sejumlah proyek infrastruktur di Indonesia disepakati untuk didanai oleh AIIB. Realisasinya, pada tanggal 24 Juni 2016 AIIB memberikan pinjaman dana sebesar US\$216,5 miliar untuk membiayai National Slum Upgrading Project. Terdapat tiga projek antara Indonesia dengan AIIB dan semua projek tersebut berfokus pada bidang infrastruktur. Tiga projek tersebut antara lain sebagai berikut;

\section{Tabel 3. Proyek infrastruktur di Indonesia yang didanai oleh AIIB}

\begin{tabular}{|l|l|l|}
\hline No & \multicolumn{1}{|c|}{ Proyek } & \multicolumn{1}{c|}{ Fokus Proyek } \\
\hline 1. & $\begin{array}{l}\text { Indonesia: National } \\
\text { Slum Upgrading } \\
\text { Project } \\
\text { Approval Date } \\
\text { June, 24 2016 }\end{array}$ & $\begin{array}{l}\text { Proyek akan memperbaiki akses terhadap } \\
\text { infrastruktur dan layanan perkotaan di daerah } \\
\text { kumuh yang ditargetkan di Indonesia. Ini akan } \\
\text { mendukung program investasi infrastruktur } \\
\text { kumuh perkotaan untuk 154 kota di bagian tengah } \\
\text { dan timur Indonesia. }\end{array}$ \\
\hline 2. & $\begin{array}{l}\text { Indonesia: } \\
\text { Regional } \\
\text { Infrastructure } \\
\text { Development Fund } \\
\text { Project } \\
\text { Approval Date } \\
\text { March, 22 2017 }\end{array}$ & $\begin{array}{l}\text { Proyek ini bertujuan untuk mendukung penataan } \\
\text { dan operasionalisasi Dana Pembangunan } \\
\text { Infrastruktur Daerah (RIDF) sebagai perantara } \\
\text { pemerintah daerah. Fokus pembangunan: } \\
\text { transportasi perkotaan; penyediaan air dan } \\
\text { sanitasi perkotaan; risiko drainase, banjir dan } \\
\text { bahaya; pengelolaan limbah padat; dan up-grade } \\
\text { kumuh dan perumahan yang terjangkau. }\end{array}$ \\
\hline 3. & $\begin{array}{l}\text { Indonesia: Dam } \\
\text { Operational } \\
\text { Improvement and } \\
\text { Safety Project Phase } \\
\text { II } \\
\text { Approval Date } \\
\text { March, 22 2017 }\end{array}$ & $\begin{array}{l}\text { Untuk meningkatkan keamanan dan } \\
\text { fungsionalitas dari 63 bendungan / waduk } \\
\text { prioritas utama yang diprakarsai, } \\
\text { Mengembangkan dan mengarusutamakan } \\
\text { pengaturan peraturan dan pengaturan untuk } \\
\text { pengelolaan bendungan dan pengelolaan waduk } \\
\text { dan keselamatan yang lebih berkelanjutan dari } \\
\text { perspektif teknis, lingkungan dan keuangan. }\end{array}$ \\
\hline
\end{tabular}


Tabel 5. Proyek infrastruktur Indonesia yang dibiayai China

\begin{tabular}{|l|l|l|l|}
\hline No & Proyek Infrastruktur China di Indonesia & Lokasi Proyek & $\begin{array}{c}\text { Tahun } \\
\text { Proyek }\end{array}$ \\
\hline 1. & Kereta Api Cepat Jakarta-Bandung & $\begin{array}{l}\text { Jakarta- } \\
\text { Bandung }\end{array}$ & $2016-2019$ \\
\hline 2. & $\begin{array}{l}\text { Pembangunan Jalan To1 Cisumdawu } \\
\text { (Cileunyi-Sumedang-Dawuan ) seksi I dan } \\
\text { II }\end{array}$ & Jawa Barat & $2016-2019$ \\
\hline 3. & Pembangunan Jalan To1 Manado-Bitung & Manado & $2016-2019$ \\
\hline 4. & Pembangunan Jalan To1 Solo-Kertosono & Solo & $2015-2017$ \\
\hline 5. & $\begin{array}{l}\text { Pembangkit Tenaga Listrik Uap (PLTU) } \\
\text { Pulang Pisang }\end{array}$ & $\begin{array}{l}\text { Kalimantan } \\
\text { Tengah }\end{array}$ & 2016 \\
\hline 6. & Pembangkit Tenaga Listrik Uap (PLTU) & Riau & $2015-2017$ \\
\hline
\end{tabular}

Upaya Indonesia untuk memperlancar arus masuk investasi asing didukung juga melalui pembentukan paket kebijakan ekonomi. Pada paket kebijakan ekonomi nomor dua yang dikeluarkan Presiden Jokowi, pemerintah berfokus untuk meningkatkan investasi asing dengan mempermudah izin berinvestasi (Kominfo, 2017). Isi paket kebijakan ekonomi nomor dua yakni kemudahan perizinan, pengurusan tax allowance dan tax holiday lebih cepat, tidak adanya pungutan PPN untuk alat transportasi, insentif fasilitas di kawasan pusat logistik berikat, insentif pengurangan pajak bunga deposito dan perampingan izin sektor kehutanan (Tempo, 2015).

\section{Indonesia-China di Perairan Natuna}

Perairan Natuna berbatasan langsung dengan Laut China Selatan yang saat ini statusnya sebagai perairan yang tumpang tindih. Laut China Selatan memiliki nilai politik, ekonomi, dan pertahanan yang tinggi. Meskipun Indonesia tidak menjadi negara yang memiliki klaim atas Laut China Selatan (Non Claimant State), namun nine dash-line yang diklaim China menyilang dengan batas utara Zona Eksklusif Ekonomi (ZEE) Indonesia di perairan Natuna. Di sinilah letak permasalahan antara Indonesia dan China.

Klaim tumpang-tindih tersebut membuat beberapa kali insiden terjadi. Insiden kapal China memasuki wilayah perairan Natuna salah satunya terjadi pada 5 Mei 2010 ketika kapal-kapal nelayan China memasuki wilayah ZEE Indonesia untuk mencuri ikan. Insiden kedua terjadi pada 22 Juni 2010 dimana nelayan-nelayan China kembali secara ilegal memasuki perairan Natuna (Aaron, 2017). Insiden ketiga terjadi pada 26 Maret 2013 
saat aparat Indonesia menangkap nelayan-nelayan China yang melakukan pencurian ikan. Sejumlah petugas penjaga pantai China yang dilengkapi dengan senjata meminta pihak Indonesia untuk melepaskan kapal nelayan China. Kejadian selanjutnya terjadi pada 22 November 2015 dimana kapal ilegal nelayan China terlihat memasuki wilayah perairan Natuna (BBC, 2017).

Pada tahun 2016 tercatat sebanyak tiga kali kapal nelayan China masuk secara ilegal dan mencuri ikan di perairan Natuna. Saat itu, kapal patroli Kementerian Kelautan dan Perikan (KKP) Indonesia menangkap kapal nelayan ilegal China di Natuna namun dilepas kembali karena munculnya kapal penjaga pantai China. Kejadian berlanjut pada 27 Mei 2016. Untuk kedua kalinya kapal-kapal nelayan China memasuki perairan Natuna. Petugas keamanan Indonesia memberikan tembakan terhadap kapal pukat China yang menolak untuk menghentikan penangkapan ikan. Petugas pun berhasil menahan kapal-kapal pukat China berserta awak kapal (DW, 2017). Pada 17 Juni 2016 KRI Imam Bonjol-383 yang sedang berpartoli menerima laporan intai udara maritim bahwa terdapat $12 \mathrm{kapal}$ nelayan China sedang mencuri ikan di perairan Natuna. Dalam insiden tersebut Indonesia melepaskan tembakan dan mengenai salah satu kapal nelayan milik China.

Tabel 6. Daftar pelanggaran kedaulatan oleh China di Natuna

\begin{tabular}{|l|l|l|}
\hline No & \multicolumn{1}{|c|}{ Tanggal } & \multicolumn{1}{c|}{ Peristiwa } \\
\hline 1 & 5 Mei 2010 & $\begin{array}{l}\text { Kapal-kapal nelayan China memasuki } \\
\text { wilayah ZEE Indonesia. }\end{array}$ \\
\hline 2 & 22 Juni 2010 China memasuki \\
\hline 3 & 26 Maret 2013 & $\begin{array}{l}\text { Kapal-kapal nelayan } \\
\text { wilayah ZEE Indonesia. }\end{array}$ \\
\hline 4 & 22 November 2015 & $\begin{array}{l}\text { Kapal-kapal nelayan China memasuki } \\
\text { wilayah ZEE Indonesia. }\end{array}$ \\
\hline 5 & 20 Maret 2016 & $\begin{array}{l}\text { Kapal-kapal nelayan China memasuki } \\
\text { wilayah ZEE Indonesia. }\end{array}$ \\
\hline 6 & 27 Mei 2016 & $\begin{array}{l}\text { Kapal patroli Kementerian Kelautan dan } \\
\text { Perikan (KKP) Indonesia menangkap } \\
\text { kapal nelayan ilegal China }\end{array}$ \\
\hline 7 & 17 Juni 2016 & $\begin{array}{l}\text { Kapal patroli Kementerian Kelautan dan } \\
\text { Perikan (KKP) Indonesia menangkap } \\
\text { kapal nelayan ilegal China }\end{array}$ \\
\hline 8 & 23 Juni 2016 & $\begin{array}{l}\text { 12 kapal nelayan China mencuri ikan di } \\
\text { perairan Natuna }\end{array}$ \\
\hline
\end{tabular}


Berulangkalinya kapal-kapal nelayan China masuk ke perairan Indonesia, mendapatkan respon dari Presiden Jokowi. Pada tanggal 23 Juni 2016 Presiden Jokowi melakukan rapat di KRI Imam Bonjol-383. Presiden Jokowi juga berdiri di atas kapal KRI Imam Bonjol-383 untuk berpatroli dikawasan pencurian ikan oleh China. Respon yang diberikan oleh Presiden Jokowi merupakan simbolisasi ketegasan sikap Indonesia atas tindakan China terhadap perairan Natuna. Sikap tersebut memberikan pesan tegas bahwa Indonesia memandang permasalahan kedaulatan Natuna dengan serius. Indonesia menilai permasalahan illegal fishing akan berpengaruh terhadap kedaulatan. Oleh sebab itu, Indonesia sangat tegas terhadap setiap bentuk pelanggaran di perairan Indonesia, termasuk di perairan Natuna yang bersinggungan dengan klaim China di Laut China Selatan. Dari hasil wawancara langsung dengan Ahmad Hanafi Rais, anggota Komisi I DPR-RI, mengatakan Indonesia memiliki kedaulatan atas ZEE di Natuna dan tidak dapat diganggu gugat oleh klaim satu pihak. Hal ini juga telah diputuskan oleh Permanent Court of Arbitration. Untuk semakin mempertegas sikap Indonesia di Natuna, dalam keterangan pers 2017 Kementerian Luar Negeri Indonesia menyatakan Indonesia hanya memiliki tumpang tindih landasan kontinen dan ZEE hanya dengan dua negara yaitu Malaysia dan Vietnam (Kementerian Luar Negeri, 2017).

Upaya China masuk ke wilayah perairan Natuna bukanlah hal yang tidak disengaja. Pada saat penggeledahan kapal nelayan China yang memasuki wilayah perairan Natuna, ditemukan sebuah peta yang dikeluarkan oleh Kantor Kemaritiman Nansha 1994 yang mencantumkan perairan di sekitar pulau Natuna sebagai wilayah penangkapan tradisional China (Kompas, 2017a). Pada tahun 1996 China pernah memberikan pernyataan bahwa Natuna (perairan Natuna) milik Indonesia (Kompas, 2017a). Namun, pada 2016 China menyatakan secara tebuka bahwa wilayah perairan Natuna merupakan wilayah penangkapan ikan bagi China (traditional Chinese fishing grounds) sejak dari dulu (Connely, 2016).

Meskipun bukan sebagai negara yang memiliki klaim pada Laut China Selatan, Indonesia memiliki beberapa kepentingan di Laut China Selatan. Kepentingan pertama adalah melindungi wilayah kedaulatan Natuna yang berdekatan dengan Laut China Selatan. Wilayah Natuna merupakan wilayah strategis yang kaya akan sumber daya alam. Menurut K.J. Holsti, kedaulatan termasuk ke dalam core values kepentingan nasional, yakni sesuatu yang dianggap paling penting bagi suatu negara yang berhubungan dengan keamanan, pertahanan dan kedaulatan (Holsti, 1970). Negara akan melakukan apapun untuk mempertahankan core values. Indonesia merasa kedaulatan di Natuna terancam dengan pencurian ikan secara ilegal oleh China. Oleh karena itu, sikap tegas Indonesia terhadap China di perairan Natuna dapat dipahami dalam kerangka kepentingan core values tersebut. Kedaulatan di perairan Natuna lebih penting daripada kepentingan 
ekonomi, yang masih dalam kategori Holsti, dikategorikan sebagai middle range interest.

Kepentingan Indonesia kedua di Natuna adalah menjaga stabilitas regional Asia Tenggara. Jika kawasan Asia Tenggara tidak aman, maka akan membawa pengaruh untuk negara-negara yang berada di kawasan Asia Tenggara, termasuk Indonesia. Pada era Presiden Joko Widodo, meski orientasi politik luar negerinya adalah inward looking, namun strategi Indonesia terhadap persengketaan Laut Cina Selatan tetap menekankan pada pendekatan aktor diplomasi aktif yang mencari penyelesaian damai untuk menghindari persengketaan yang lebih luas. Hal ini demi melindungi kepentingan-kepentingannya sendiri di sekitar Kepulauan Natuna.

Kepentingan ketiga adalah menjaga integritas hukum UNCLOS (United Nations Convention on the Law of the Sea). Pada Juli 2010 Indonesia menulis dalam catatan verbal kepada Seketaris Jendral Persikatan Bangsa-Bangsa (PBB) bahwa klaim China tentang sembilan garis putus-putus, "tidak memiliki basis hukum internasional" (Connely, 2016). Menurut hukum internasional klaim China di Laut China Selatan tidak memiliki dasar hukum yang kuat. Itu sebabnya, untuk mempertegas kepemilikan Indonesia di Natuna, komitmen Indonesia terhadap UNCLOS menjadi prioritas.

Sebagai non-claimant states, Indonesia dapat memainkan peran sebagai honest broker (perantara yang tidak memihak) dalam penyelesaian sengketa di Laut China Selatan (Severino, 2010). Peran sebagai honest broker dalam konflik di Laut China Selatan telah dijalankan sejak tahun 1990. Hal tersebut diwujudkan dengan peran Indonesia menjadi tuan rumah lokakarya-lokakarya permasalahan Laut China Selatan sejak tahun 19902014 (Djalal, 2003). Sebagai contoh, dalam lokakarya ke-19 di Makasar, dibahas mengenai perkembangan berbagai proyek kerjasama yang telah disepakati, yang meliputi Regional Cooperation in the Field of Marine Science and Information Network in the South China Sea including Database Information Exchange and Networking Project (China), Study of Tides and Sea Level Change and Their Impacts on Coastal Environment in the South China Sea Affected by Potential Climate Change (Indonesia), Training Program for Marine Ecosystem Monitoring (the Philippines), Search and Rescue and Illegal Acts including Piracy and Armed Robbery (Kementerian Luar Negeri, 2009). Pada lokakarya ini juga dicapai suatu kemajuan dengan inisiatif dari peserta China dan Taiwan dalam suatu joint project dengan tema Southeast Asia Network for Education and Training project. Kegiatan ini merupakan proyek pelatihan dan pertukaran tenaga ahli untuk pengembangan kapasitas di bidang oceanography, remote sensing, modelling, marine ecology, fishery management, ocean science, ocean and coastal management dan marine environmental protection (Kementerian Luar Negeri, 2009). 
Kebijakan Indonesia di Laut China Selatan menjadi lebih 'agresif' pada 2017, yaitu dengan mengubah nama perairan Natuna menjadi perairan Natuna Utara (Kompas, 2017a). Selain dikarenakan nama tersebut mengacu pada sebelah utara Natuna yang merupakan ZEE Indonesia, berdasarkan keterangan dari Deputi Kementerian Koordinator Bidang Maritim Arif Havas Oegroseno, penamaan ini dilakukan karena dua alasan. Pertama, untuk mencegah kebingungan di antara pihak-pihak yang ingin mengeksploitasi landas kontinen tersebut, mengingat wilayah itu adalah teritori kedaulatan Indonesia; dan kedua, untuk memberikan petunjuk yang jelas kepada Tim Penegakan Hukum di Angkatan Laut Indonesia (Leo, 2016). Namun hal ini mengundang protes dari China. Tapi sikap China tersebut tidak menghalangi sikap yang diambil Indonesia untuk tetap melakukan pendafataran ke PBB (CNN, 2017).

China sangat paham, dibutuhkan upaya ekstra untuk dapat melunakan sikap negara-negara di ASEAN untuk bisa sejalan dengan kepentingannya di Laut China Selatan. Untuk hal ini, salah satu instrumen yang digunakan China adalah melalui komitmen bantuan dana investasi. Agenda OBOR China, menjadi cara bagi China untuk mendekat kepada negara-negara ASEAN yang memiliki persinggungan dengannya di Laut China Selatan, seperti Vietnam, Filipina, Malaysia, Brunei Darussalam, termasuk Indonesia. (Kompas, 2016)

Pendekatan China melalui instrumen investasi membuat beberapa rivalnya berubah. Sebagai contoh perubahan sikap Filipina pasca disepakatinya 30 proyek kerjasama senilai Rp. 494 triliun (CNN, 2017). Sikap Filipina di masa Presiden Benigno Aquino III sangat menentang klaim China di Laut China Selatan. Saat itu Filipina bahkan membawa permasalahan klaim Laut China Selatan ke Mahkamah Arbitrase di Den Haag yang kemudian memenangkan klaim Filipina (BBC, 2017). Namun demikian, China tidak menerima keputusan tersebut dan tetap mengklaim Laut China Selatan. Namun, sikap Filipina kemudian melunak pasca penandatanganan proyek bersama yang dilakukan pada era Presiden Rodrigo Duterte. Lebih jauh, kedua negara menyatakan jika penyelesaian permasalahan Laut China Selatan antara Filipina dan China akan diselesaikan secara bilateral (DW, 2017).

Selain Filipina, sikap Malaysia dengan China terhadap Laut China Selatan juga berubah. Pasca kunjungan Perdana Menteri Najib Razaq ke China, disepakati 10 kerjasama proyek China di Malaysia. Salah satunya adalah proyek infrastruktur kereta cepat yang menghubungkan Malaysia-Singapura senilai US\$15 miliar (Ariyanti, 2015). Pasca kesepakatan tersebut, Malaysia menyatakan sikapnya untuk menyelesaikan permasalahan Laut China Selatan secara damai dengan China. 
Sikap Brunei Darussalam dalam isu China di Laut China Selatan juga berubah. Awalnya, Brunei Darussalam menjadi salah satu negara di Asia Tenggara yang menentang klaim China di Laut China Selatan. Klaim China di Laut China Selatan bersingungan dengan Louisa Reef ZEE Brunei. Namun sikap tersebut kemudian berubah pasca China memberikan bantuan kepada Brunei untuk pengeboran minyak di wilayah Louisa Reff. Perusahaan China Guangxi Beibu Gulf International Port Group Co pada 2016 menandatangani syarat untuk membentuk usaha patungan di Brunei dan menjalankan pelabuhan utama negara tersebut (Jenings, 2017).

Satu-satunya negara pengklaim yang konsisten dengan sikapnya adalah Vietnam. Vietnam tetap tidak menerima klaim China di Laut China Selatan, meskipun kerja sama ekonomi China dan Vietnam tergolong tinggi. Data kepabeanan Vietnam menyebut ekspor Vietnam ke China melonjak 43 persen menjadi US\$13 miliar pada semester I 2017. Sedangkan impor mencapai 16 persen. Tidak adanya perubahan sikap Vietnam terhadap China disebabkan adanya dukungan AS. Investasi China di Vietnam ternyata tidak berhasil mengubah sikap Vietnam. Meskipun demikian, Vietnam dan China sepakat menyelesaikan permasalahan Laut China Selatan secara damai dan akan menjaga perdamian di Asia Tenggara (Antara, 2017).

Negara-negara Asia Tenggara lain yang tidak mempunyai klaim di Laut China Selatan memiliki suara tersendiri. Kamboja dan Laos lebih condong ke China. Pada KTT ASEAN 2012 di Kamboja, Kamboja menolak pembahasan isu Laut China Selatan dimasukkan pada KTT tersebut (VOA, 2012). Hal tersebut memperjelas memperjelas dukungan Kamboja kepada China. Myanmar dan Thailand juga menyatakan sepenuhnya dukungannya terhadap China dan mendorong negosiasi untuk menyelesaikan masalah Laut Cina Selatan secara damai (Khapoor \& Sieg, 2017).

Berbeda dengan negara lainnya, sikap Indonesia dalam isu Laut China Selatan tetap konsisten. Sebagai negara non-claimant state Indonesia memiliki sikap tegas atas kepentingan di laut China Selatan, terutama untuk melindungi kedaulatan Kepulauan Natuna. Meskipun Indonesia menerima banyak investasi dari China, hal ini tidak mengubah posisi Indonesia. Sikap tegas Indonesia juga disampaikan oleh Presiden Jokowi yang menyatakan, "bahwa salah satu klaim utama China terhadap sebagian besar Laut China Selatan tidak memiliki dasar hukum dalam hukum internasional, namun Jakarta (Indonesia) ingin tetap menjadi "Honest Broker" dalam salah satu sengketa teritorial Asia yang paling berduri" (DW, 2017). 
Tabel 7. Pengaruh Investasi China terhadap Sikap Negara-negara ASEAN dalam isu Laut China Selatan

\begin{tabular}{|l|l|l|l|}
\hline No & \multicolumn{1}{|c|}{ Negara } & \multicolumn{1}{|c|}{$\begin{array}{c}\text { Sikap sebelum adanya } \\
\text { investasi China }\end{array}$} & \multicolumn{1}{|c|}{$\begin{array}{c}\text { Sikap setelah adanya } \\
\text { investasi China }\end{array}$} \\
\hline 1. & Filipina & Tidak mendukung China & Mendukung China \\
\hline 2. & Malaysia & Tidak mendukung & Mendukung China \\
\hline 3. & Indonesia & Netral & $\begin{array}{l}\text { Netral ( sikap tidak } \\
\text { berubah) }\end{array}$ \\
\hline 4. & Kamboja & Mendukung China & Mendukung China \\
\hline 5. & $\begin{array}{l}\text { Brunei } \\
\text { Darussalam }\end{array}$ & Tidak mendukung China & Mendukung China \\
\hline 6. & Laos & Mendukung China & Mendukung China \\
\hline 7. & Vietnam & Tidak mendukung China & Tidak mendukung China \\
\hline 8. & Myanmar & Netral & $\begin{array}{l}\text { Netral (sikap tidak } \\
\text { berubah ) }\end{array}$ \\
\hline 9. & Singapura & Netral & $\begin{array}{l}\text { Netral ( sikap tidak } \\
\text { berubah) }\end{array}$ \\
\hline 10. & Thailand & Mendukung China & Mendukung China \\
\hline
\end{tabular}

\section{Kesimpulan}

Artikel ini dilatarbelakangi oleh situasi peningkatan kerjasama ekonomi Indonesia-China yang diiringi dengan ketegangan kedua negara di perairan Natuna. Pada bidang ekonomi, hal ini terutama ditandai dengan peningkatan kerjasama ekonomi kedua negara, baik pada sektor investasi maupun perdagangan. Meski demikian, hubungan kedua negara juga memiliki ketegangan pada bidang kedaulatan teritorial, terutama dalam isu Laut China Selatan. Dengan profil yang tampak bersebarangan tersebut, apakah dua dinamika yang berbeda ini saling mempengaruhi?

Artikel ini berargumen bahwa dua dinamika berbeda yang melingkari hubungan Indonesia-China tidak memiliki pengaruh yang signifikan satu sama lain. Hal ini disebabkan diplomasi Indonesia dengan China dalam bidang ekonomi dan kedaulatan memiliki karakter dan struktur kepentingan yang berbeda. Pada bidang ekonomi, hubungan Indonesia dan China dijalin atas prinsip kerjasama yang pragmatis dalam upaya peningkatan hubungan perdagangan dan investasi. Sementara pada bidang kedaulatan, hubungan kedua negara berpijak pada prinsip kepentingan strategis. Dari pembahasan juga dapat disimpulkan bahwa aliran investasi China ke Indonesia dalam sejumlah pembiayaan infrastruktur, tidak mempengaruhi ketegasan Indonesia dalam mempertahankan kedaulatan Natuna. Artikel 
ini menunjukan sikap Indonesia yang jelas berbeda dengan kebanyakan negara-negara di ASEAN yang memiliki konflik serupa dengan China di Laut China Selatan.

\section{Daftar Pustaka}

AIIB (2017). Asian Infrastructure Investment Bank [Online]. Tersedia dalam: <https://www.aiib.org/en/about-aiib/index.html> (Diakses 14 Agustus 2017)

Andika, M. T. (2016) An Analysis of Indonesia Foreign Policy Under Jokowi's Pro-People Diplomacy. Indonesian Perspective 1(2), pp. 93-105.

Antara News (2017) China Sepakat Dengan Vietnam Terkait Pengelolaan Laut China Selatab [Online]. Tersedia dalam: <https://www.antaranews.com/berita/662668/china-sepakat-dengan-vietnam-terkait-pengelolaan-laut-china-selatan> (Diakses 20 Desember 2017).

Ariyanti, F. (2015) Alasan Proposal Kereta Cepat Jepang Kalah dari China [Online], Tersedia dalam: <http://bisnis.liputan6.com/read/2333913/ alasan-proposal-kereta-cepat-jepang-kalah-dari-china> (Diakses 15 Agustus 2017).

BBC (2016) TTP: What is it and Why does matter? [Online], Tersedia dalam: $<$ http://www.bbc.com/news/business-32498715> (Diakses 15 Agustus 2017).

BKPM (2016) 2 Tahun Jokowi-JK Realisasi Investasi China Naik Tajam [Online]. Tersedia dalam: <http://www.bkpm.go.id/id/publikasi/detail/ berita-investasi/2-tahun-jokowi-jk-realisasi-investasi-china-naik-tajam> (Diakses 17 Agustus 2017).

Cai, P. (2017) Understanding China's Belt and Road Initiative [Online], Tersedia dalam: <https://www.lowyinstitute.org/sites/default/files/documents/Understanding\%20China\%E2\%80\%99s\%20Belt\%20and\%20 Road\%20Initiative_WEB_1.pdf> (Diakses 15 Agustus 2017).

CNN (2017) Diprotes China, RI Daftarkan Nama Laut Natuna Utara ke PBB [Online], Terdapat dalam: <https://www.cnnindonesia.com/internasional/20170720172204-106-229239/diprotes-china-ri-daftarkan-nama-laut-natuna-utara-ke-pbb> (Diakses 20 Oktober 2017).

Connely, A. (2016) Indonesia di Laut China Selatan: Berjalan Sendiri [Online], Terdapat dalam: <https://www.lowyinstitute.org/publications/ indonesia-laut-cina-selatan-berjalan-sendiri> (Diakses 20 Januari 2017)

Djalal, H. (2003) Preventive Diplomacy in Southeast Asia: Lessons Learned. Jakarta: The Habibie Center.

Duta, D.K. (2015). Jokowi kuatkan kerjasama ekonomi Indonesia Tingkok [Online]. Tersedia dalam: <http://www.cnnindonesia.com/ ekonomi/20150329104005-92-42712/jokowi-kuatkan-kerjasama-ekonomi-indonesia-tiongkok/> (Diakses 22 Maret 2017) 
DW (2017) Jokowi kunjungi Natuna isyarat tegas buat China [Online]. Tersedia dalam: <http://www.dw.com/id/jokowi-kunjungi-natuna-isyarat-tegas-buat-cina/a-19349442> (Diakses 17 Agustus 2017)

Ferida, K. (2016) Setelah Filipina, Giliran Malaysia Merapat ke China [Online], Tersedia dalam: <http://global.liputan6.com/read/2640907/ setelah-filipina-giliran-malaysia-yang-merapat-ke-china> (Diakses 20 Desember 2016).

Habir, D., Ahmad.,et.all. (2014) Normative Priorities And Contradictions in Indonesia's Foreign Policy: From Wawasan Nusantara to Democracy. Australia: National Security College Issue Brief.

Holsti, K. J. (1970) National role conceptions in the study of foreign policy. International Studies Quarterly 14(3), pp. 233-309.

Jening, R. (2017) China is Pursuing This Quite, Loyal Ally in Asia's Big Maritime Dispute [Online]. Tersedia dalam: <https://www.forbes.com/ sites/ralphjennings/2017/03/06/why-brunei-will-always-be-nice-tochina-in-their-sticky-maritime-dispute/> (Diakses 15 Juli 2017).

Kamrany, N. M. \& Jiang, F. (2016). China's Rise to Global Economic Superpower [Online]. Tersedia dalam : http://www.huffingtonpost.com/ nake-m-kamrany/chinas-rise-to-global-eco_b_6544924.html (Diakses 21 Agustus 2017).

Kementerian Komunikasi dan Informatika Republik Indonesia (2015) Paket Kebijakan Ekonomi jilid II [Online]. Tersedia dalam: <//www.kominfo.go.id/content/detail/6101/paket-kebijakan-ekonomi-jilid-ii/0/ berita> (Diakses 17 Agustus 2017).

Kementerian Luar Negeri Republik Indonesia (2017) List of Treaties of Concluded by Indonesia [Online], Tersedia dalam: <http://treaty.kemlu. go.id/> (Diakses 15 Agustus 2017).

Kementerian Luar Negeri Republik Indonesia (2017) Pernyataan Pers Tahunan Menteri Luar Negeri Indonesia 2017 [Online]. Tersedia dalam: <https://www.kemlu.go.id/id/berita/Pages/Pernyataan-Pers-Tahunan-Menteri-Luar-Negeri-Tahun-2017.aspx> (Diakses 20 Maret 2017).

Kementerian Luar Negeri Republik Indonesia (2017) Treaty Room [Online]. Tersedia dalam : <http://treaty.kemlu.go.id/index.php/treaty/index?Treaty\%5Bcountry_id\%5D=33\&Treaty\%5Bwork_type_id\%5D=1> (Diakese 15 Agustus 2017).

Khapoor, K. \& Sieg, L. (2017) Indonesian president says China's main claim in South China Sea has no legal basis [Online], Tersedia dalam: $<$ http:// www.reuters.com/article/us-indonesia-china-southchinasea-idUSKBN0MJ04320150323> (Diakses 18 Agustus 2017).

Kompas (2015) Indonesia Tiongkok Sepakati Kerja Sama di Delapan Bidang [Online]. Tersedia dalam: <http://nasional.kompas.com/ $\mathrm{read} / 2015 / 03 / 26 / 22510981 /$ Indonesia-Tiongkok.Sepakati.Kerja.Sama. 
di.Delapan.Bidang> (Diakses 22 Maret 2017)

Kompas (2016) Presiden Jokowi Terima Delegasi Partai Komunis China [Online]. Tersedia dalam: <http://nasional.kompas.com/ $\mathrm{read} / 2016 / 04 / 13 / 16362071 /$ Presiden.Jokowi.Terima.Delegasi.Partai. Komunis.China> (Diakses 16 Agustus 2017).

Kompas (2017a) Jokowi Dijadwalkan Temu Bilateral dengan Presiden China Xi Jinping [Online]. Tersedia dalam: <http://nasional.kompas. com/read/2017/05/14/06580511/jokowi.dijadwalkan.temu.bilateral. dengan.presiden.china.xi.jinping> (Diakses 17 Agustus 2017).

Kompas (2017b) Butuh Beberapa Triliun Untuk Membangun Indonesia hingga 2019 [Online], Tersedia dalam: <http://ekonomi.kompas.com/ $\mathrm{read} / 2017 / 04 / 26 / 193000426 /$ butuh.berapa.triliun.untuk.membangun. indonesia.hingga.2019> (Diakses 15 Agustus 2017).

Kurniawati, D. (2016) Indonesia China Complicated Relations [Online]. Tersedia dalam: <http://www.asiasentinel.com/politics/indonesia-china-complicated-relations/> [Diakses 14 Agustus 2017].

Laurence, H. (2007) The ASEAN Way and Community Integration: Two Different Models of Regionalism. European Law Journal 13(6), pp. 857-879.

Pham, T. N. (2016) Why The US Rebalance to Asia is More Import Than Ever [Online], Tersedia dalam: <http://thediplomat.com/2016/06/ why-the-us-rebalance-to-asia-is-more-important-than-ever/> (Diakses 14 Agustus 2017).

Poole, A. (2014) The Foreign Policy Nexus; National Interests, Political Values, and Identity. Australia: National Security College Issue Brief.

Saverino, R. (2010) ASEAN and the South China Sea Security Challenges [online]. Tersedia dalam: <https://www.regionalsecurity.org.au/.../ vol6no2Severino.pdf $>$ (Diakses 25 Januari 2016)

Setiawan, A. (t.t). Indonesia Foreign's Policy Priorities in 5 Years Ahead [Online], Tersedia dalam: <http://setkab.go.id/en/indonesias-foreign-policy-priorities-in-5-years-ahead/> (Diakses 23 September 2015)

Suryadinata, L. (2016) Nationalistic Symbolism Behind Natuna [Online], Tersedia dalam: <http://www.straitstimes.com/opinion/nationalistic-symbolism-behind-natuna-sea> (Diakses pada tanggal 20 November 2017).

Tayfur, F. (1994) Main Approaches to the Study of Foreign Policy: A Review. UK: METU Studies in Develompment.

Tempo (2015) Ini Isi Lengkap Paket Kebijakan Ekonomi Jokowi Tahap Dua [Online], Tersedia dalam: <https://bisnis.tempo.co/read/705027/iniisi-lengkap-paket-kebijakan-ekonomi-jokowi-tahap-dua> (Diakses 27 Januari 2017).

Viva News (2015) Jokowi ke Beijing perkuat hubungan strategis RI dan China [Online]. Tersedia dalam: <http://dunia.news.viva.co.id/news/ read/606571-jokowi-ke-beijing-perkuat-hubungan-strategis-ri-danchina> (Diakses 22 Maret 2017).

Sumber Lainnya: Wawancara dengan Hanafi Rais, Anggota DPR RI Komisi I. 179 